\title{
Seismic Vulnerability Assessment of Typical Stone Masonry Building
}

\author{
Kshitiz Paudel",1 \\ ${ }^{1}$ Department of Civil Engineering, Thapathali Campus, Institute of Engineering, \\ Tribhuvan University, Kathmandu, Nepal \\ *Corresponding Email: paudelkshitiz@gmail.com
}

\begin{abstract}
Masonry, the most commonly used building typology is the building of structures from individual units, which are often laid in and bound together by mortar. Masonry structures are the most vulnerable with external forces. Nepal is disaster prone zone and get frequently attack by various hazard such as earthquake, wind storms, flash-floods, fire, landslides, heavy rain fall, lightening and many more. So, in order to maintain resistive structures, seismic vulnerability of structure should be examined. Nepal Population and housing Census 2011, total 3350143 (2,397,441 -Mud bonded bricks/stone and 952,702Cement Bonded bricks/ stone) houses out of 5423297 (61.77\%) are found to be have masonry foundations. So, to link the context of Resistance structures in Nepal's context first of all, the predominating stone masonry spread widely over Nepal must be checked for their seismic vulnerability. So, a typical residential stone masonry building is taken for this study. Seismic Vulnerability of the Building is examined in accordance with guidance provided by Government of Nepal- Ministry of Physical Planning and Works, 2011 in their guideline which describe the procedure for qualitative and quantitative assessment of structural earthquake vulnerability of public and private buildings in Nepal. Furthermore, Building is modelled and analyzed by using ETABS software. The outcome obtained from ETABS software are used to find the condition of building and to propose method for its strengthening.
\end{abstract}

Keywords: Nepal, Seismic Vulnerability, Stone Masonry Buildings

\section{INTRODUCTION}

Masonry, the most commonly used building typology is the building of structures from individual units, which are often laid in and bound together by mortar. A built-up construction or combination of building units or materials of clay, shale, concrete, glass, gypsum, stone or other approved units bonded together with or without mortar or grout or other accepted methods of joining.[2] Being a heterogeneous composition of masonry units and mortar, Masonry's properties are directly dependent on the geometry and mechanical properties of its constituents, arrangement of masonry units and workmanship. 
Masonry structures are the most vulnerable with external forces. Normally these are designed for vertical loads and since masonry has adequate masonry compressive strength, the structure behaves well as long as the loads are vertical. When these structures are subjected to lateral inertial loads during an earthquake, the wall develops shear and flexure stresses. The strength of masonry under these conditions often depends on the bond between units and mortar, which is quite poor. Shear failure in the form of diagonal crack is observed due to this. [3]

Native country Nepal is disaster prone zone. Nepal lies on one of the most seismically active zone in the world. By the end of 2017, 213807 earthquakes have been recorded by the National Seismological Centre (NSC), Nepal out of which 108007 are local \& regional and 105800 are teleseisms (http://seismonepal.gov.np).Recently, on 25 April 2015 Nepal was hit by the devastating Gorkha Earthquake-Mw 7.8. The earthquake was followed by a series of aftershocks. Besides earthquake Nepal frequently got hit by various other hazards namely; wind storms, flash-floods, fire, landslides, heavy rain fall, lightening. These hazards directly affect the life of people by causing fatalities and damage to their households. Total 1,085,796 houses were damaged on the year 2015/16 in Nepal[4].Due to vast variation in construction techniques and improper knowledge about the safety factors the building get damage due to such hazard. The non-engineered design of masonry building (stone masonry) widely extended around the nation is more vulnerable to these scenarios and get disproportionally high level of damage when subjected to those events. Nepal Population and housing Census 2011, total 3350143 (2,397,441 -Mud bonded bricks/stone and 952,702- Cement Bonded bricks/ stone) houses out of 5423297 (61.77\%)[5] are found to be have masonry foundations. So, to link the context of Multi-Hazard Resistance in Nepal's context first of all, the predominating stone masonry spread widely over Nepal must be checked for their vulnerability subjected to multi-hazards. [4]

Table 22. Aggregate disaster data on economic and financial loss (2015 and 2016)

\begin{tabular}{l|c|c|c|c}
\multirow{2}{*}{ Type of disaster } & \multirow{2}{*}{$\begin{array}{c}\text { Number of } \\
\text { events }\end{array}$} & $\begin{array}{c}\text { Houses } \\
\text { damaged }\end{array}$ & $\begin{array}{c}\text { Economic loss } \\
\text { (in NRs.) }\end{array}$ & Families affected \\
\cline { 3 - 5 } & & 0 & 0 & 8 \\
\hline Boat capsize & 4 & $1,072,093$ & $706,461,000,000$ & $1,072,093$ \\
\hline Earthquake & 70 & 0 & 0 & 20 \\
\hline Epidemic & 5 & 2,997 & $2,420,480,490$ & 3,898 \\
\hline Fire & 1,856 & 2,628 & $47,296,501$ & 7,141 \\
\hline Flood & 244 & 2,980 & $811,084,600$ & 1,936 \\
\hline Landside & 290 & 2,486 & $18,969,500$ & 683 \\
\hline Heavy rainfal & 118 & 2,547 & $24,186,000$ & 191 \\
\hline Wind storm & 43 & 65 & $5,271,000$ & 415 \\
\hline Lightning & 299 & & &
\end{tabular}

Q. of H. A. Goveraunet of Niqal. 2017)

\section{ADOPTED VULNERABILITY ASSESSMENT METHODOLOGY}

The research methodology followed here includes combined steps of Seismic Vulnerability Evaluation Guidelines for Private and Public Buildings, Nepal and ISO:13822 includes:[6] 


\section{Flowchart for the general assessment of existing structures}

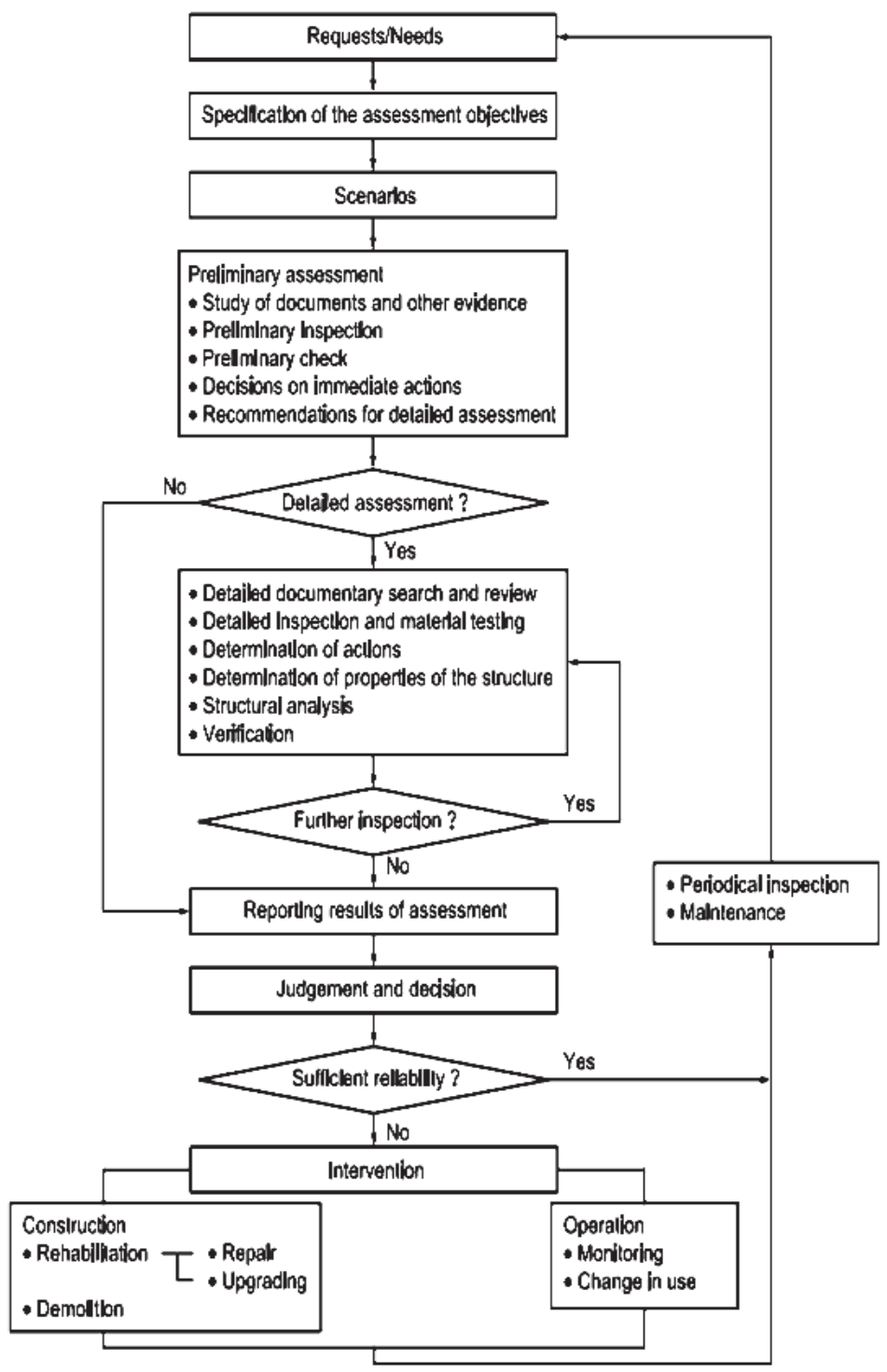

\section{QUALITATIVE SEISMIC VULNERABILITY ASSESSMENT}

\subsection{ASSESSMENT OF THE BUILDING}

Qualitative structural assessment of the building is done based on review of all available documents and as-built set of drawing. Different seismic vulnerability factors are checked and expected and performance 
of the building is estimated for different earthquake intensities. Different steps of the assessment process and their outcomes are described in this section.

\subsubsection{IDENTIFICATION OF SEISMICITY OF THE REGION}

The region of seismicity of the building is identified. This is done locating the building in seismic hazard map of the region in which the building stands. The zone map of Nepal is provided in Nepal National Building Code NBC 105: 1994 (Figure 8.2: SEISMIC ZONING FACTOR, Z). [7]

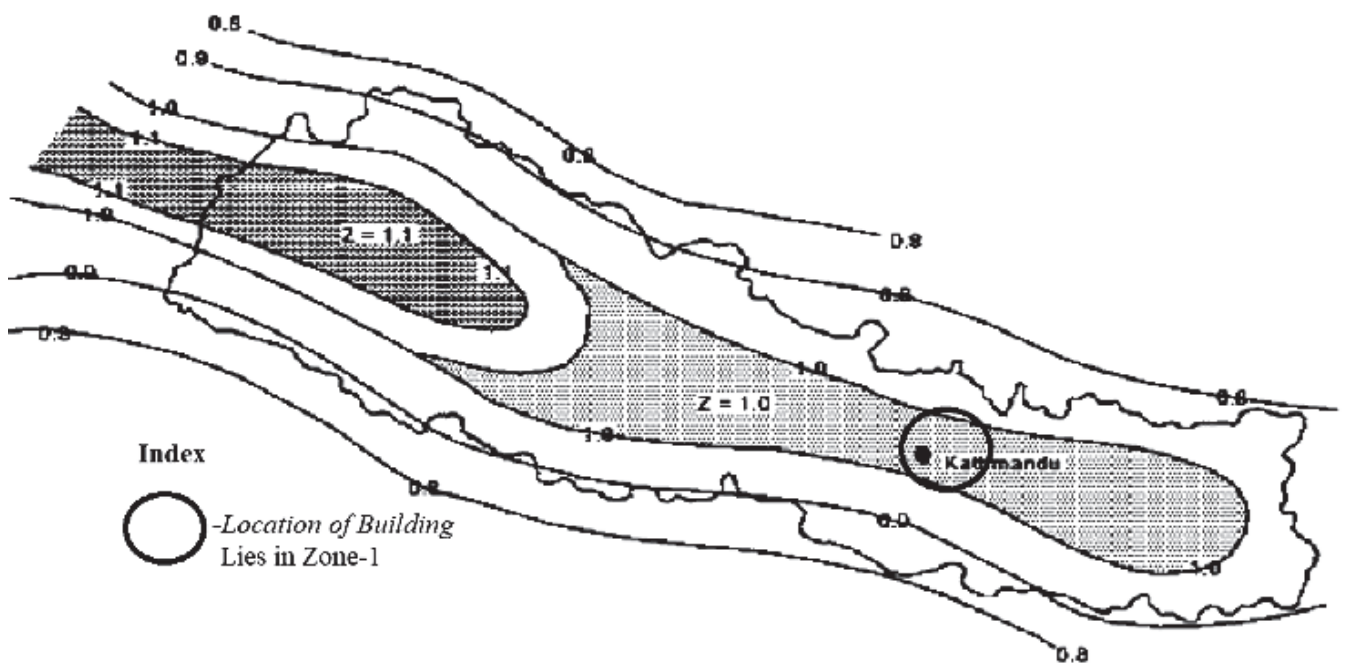

\subsubsection{ESTABLISH SEISMIC TARGET PERFORMANCE LEVEL}

Desired performance level of protection is established prior to conducting seismic evaluation and strengthening. These are classified as:

- Operational

- Immediate occupancy

- Life safety (Residential Buildings)

- Collapse Prevention 


\subsubsection{OBTAIN AS-BUILT INFORMATION}

\begin{tabular}{|c|c|c|c|}
\hline \multicolumn{4}{|l|}{ AS Built Information; } \\
\hline Component & \multicolumn{3}{|c|}{ Details (Mfaterial Used, Specifications) } \\
\hline $\begin{array}{l}\text { Foundation(visual } \\
\text { inspection or interview } \\
\text { with house owner): }\end{array}$ & $\begin{array}{l}\text { Material: Stone and } \\
\text { Mud }\end{array}$ & Depth(ft): $9.5 \mathrm{ft}$ & Width(ft): $4.5 \mathrm{ft}$ \\
\hline $\begin{array}{l}\text { Tertical Reinforcement ( } \\
\text { if available mention size } \\
\text { or N/A if not available) }\end{array}$ & N/A & N/A & N/A \\
\hline \multirow[t]{2}{*}{ Wall Size: } & \multirow[t]{2}{*}{$\begin{array}{l}\text { Material: Stone in } \\
\text { Mud Mortar }\end{array}$} & $\begin{array}{l}\text { Width: } 24 \text { inch } \\
\text { with plaster in } \\
\text { outer walls }\end{array}$ & Quality: Not Bad \\
\hline & & $\begin{array}{l}\text { Width: } 18 \text { inch } \\
\text { with plaster in } \\
\text { partition wall }\end{array}$ & Quality: Not Bad \\
\hline $\begin{array}{l}\text { Wall Laying } \\
\text { (Distinguish on the basis } \\
\text { on stone quality, wall } \\
\text { laying and use of through } \\
\text { stones): }\end{array}$ & \multicolumn{3}{|c|}{$\begin{array}{l}\text { Wall type is Stone Masonry with Mud Mortar, through stones are } \\
\text { used at 2-3ft spacing. Stone quality is normal. }\end{array}$} \\
\hline $\begin{array}{l}\text { Horizontal Band \& } \\
\text { Stiches: (if available } \\
\text { mention size and vertical } \\
\text { Spacing between bands } \\
\text { or N/A if not available): }\end{array}$ & \multicolumn{2}{|c|}{$\begin{array}{l}\text { No lintel and sill band in ground floor. } \\
\text { Sill band is present in first floor's north } \\
\text { wall. But laying of reinforcement is done } \\
\text { in wrong way. Instead of c hooks, long z } \\
\text { shaped reinforcement are placed such that } \\
\text { they are exposed to air, }\end{array}$} & $\begin{array}{l}\text { 2-10mm longitudinal } \\
\text { reinforcement. } \\
\mathrm{Z} \text { shaped hooks of } 8 \mathrm{~mm} \\
\text { a } 6^{\prime \prime} \mathrm{c} / \mathrm{c}\end{array}$ \\
\hline $\begin{array}{l}\text { Flooring: (mention the } \\
\text { size of rafters spacing, } \\
\text { type f floor heavy or light } \\
\text { weight, material used for } \\
\text { flooring, and connection } \\
\text { of wooden member with } \\
\text { wall, specify if chukul is } \\
\text { used or not) }\end{array}$ & \multicolumn{2}{|c|}{ 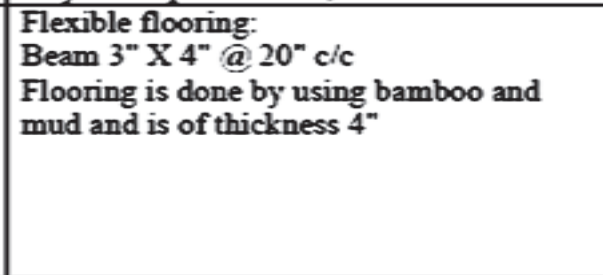 } & $\begin{array}{l}\text { Chukul has not been } \\
\text { placed. Nails are used } \\
\text { for connection purpose }\end{array}$ \\
\hline Gable Band & \multicolumn{2}{|l|}{ N/A } & N/A \\
\hline $\begin{array}{l}\text { Roofing: (mention the } \\
\text { size of rafters used and } \\
\text { spacing, material used for } \\
\text { roofing and inspect the } \\
\text { connection between roof } \\
\text { elements and its } \\
\text { connection with wall) }\end{array}$ & $\begin{array}{l}\text { Flexible roofing: } \\
\text { - Battens: } 1.5^{\prime \prime} \times 3^{\prime \prime} \\
\text { a } 4^{\prime} \mathrm{c} / \mathrm{c} \\
\text { Rafter: } 3^{\prime \prime} \times 4^{\prime \prime} \text { a } \\
1.5^{\prime \prime} \text { cic } \\
\text { Joist: } 2^{\prime \prime} \text { diameter } \\
\text { a } 1.5^{\prime \prime} \text { c/c } \\
\text { Ridge board: } 1.5^{\prime \prime} \\
\text { diameter }\end{array}$ & $\begin{array}{l}\text { Newly made } \\
\text { roofing after } \\
\text { demolition of } \\
\text { attic portion } \\
\text { since gable wall } \\
\text { collapsed during } \\
\text { earthquake. }\end{array}$ & $\begin{array}{l}\text { Chukul has not been } \\
\text { placed. Nails are used } \\
\text { for connection purpose }\end{array}$ \\
\hline \multicolumn{4}{|l|}{ Slab Beam } \\
\hline Openings: & \multicolumn{2}{|c|}{$\begin{array}{l}\text { Material: Wood } \\
\text { One door is attached to the partition wall. } \\
\text { Windows are placed at the distance of at } \\
\text { least } 2^{\prime} 7^{\prime} \text { from outer comer }\end{array}$} & $\begin{array}{l}\text { Opening criteria is of } \\
16.6 \%\end{array}$ \\
\hline
\end{tabular}




\subsubsection{BUILDING TYPOLOGY IDENTIFICATION}

Stone in Mud: These are stone-masonry buildings constructed using dressed or undressed stones with mud mortar. These types of buildings have generally flexible floors and roof.

\subsubsection{DETERMINING FRAGILITY OF THE IDENTIFIED BUILDING TYPOLOGY}

The probable damage to the building structures, that are available in Nepal and the region, at different intensities are as

From Table 2 (a) Building Fragility: Adobe+ Field Stone Masonry Building [1]

\begin{tabular}{|l|l|c|c|c|c|}
\hline \multicolumn{2}{|c|}{$\begin{array}{c}\text { Shaking Intensity } \\
\text { (MII) }\end{array}$} & VI & VII & VIII & IX \\
\hline \multicolumn{2}{|c|}{ PGA (\%) } & $\mathbf{5 - 1 0}$ & $\mathbf{1 0 - 2 0}$ & $\mathbf{2 0 - 3 5}$ & $>\mathbf{3 5}$ \\
\hline \multirow{2}{*}{$\begin{array}{l}\text { Damage } \\
\text { Grade } \\
\text { for different } \\
\text { classes of } \\
\text { buildings }\end{array}$} & Weak & DG4 & DG5 & DG5 & DG5 \\
\cline { 2 - 6 } & Average & DG3 & DG4 & DG5 & DG5 \\
\cline { 2 - 6 } & Good & DG2 & DG3 & DG4 & DG4 \\
\hline
\end{tabular}

\subsubsection{IDENTIFICATION OF VULNERABILITY FACTORS \\ Vulnerability Factors Identification}

Appropriate checklists cover the basic vulnerability factors related to building systems, lateral force resisting systems, connections and diaphragms which will be evaluated mostly based on visual observation.

Structural Assessment Checklist for Type 1 Buildings (Adobe, Stone in Mud, Brick in Mud) Adopted from Seismic Vulnerability Evaluation Guideline for Private and Public Buildings. 2011 [1] Building System

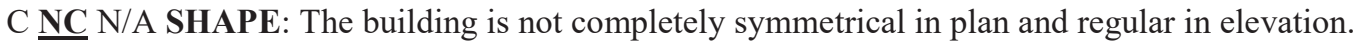

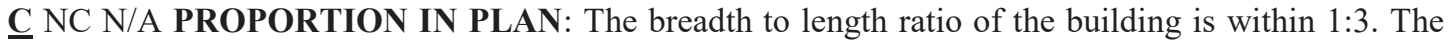
building height is no more than three times the width of the building.

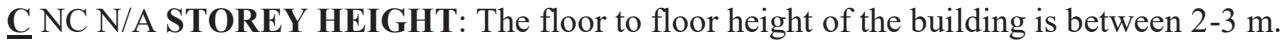

C NC N/A NUMBER OF STORIES: The building is up to two stories only.

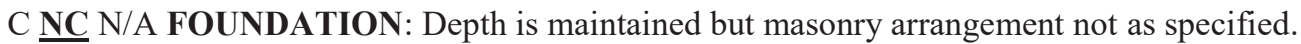

C NC N/A SLOPING GROUND: The slope of the ground is plain.

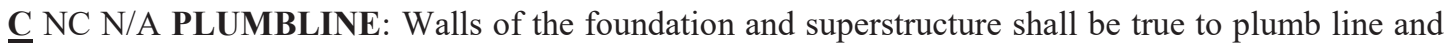
the width of the wall shall be uniform.

C NC N/A WALL CORE: There shall be no mortar packing in the core of the wall.

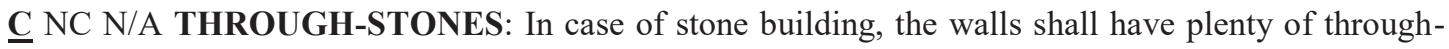
stones extending the whole width of the walls. The maximum spacing of such through-stones shall be within $1.2 \mathrm{~m}$ horizontally and $0.6 \mathrm{~m}$ vertically.

C NC N/A WALL THICKNESS: The minimum wall thickness for stone masonry type in mm for Two storey heights shall not be less than $450 \mathrm{~mm}$.

C NC N/A UNSUPPORTED WALL LENGTH: The maximum length of unsupported wall shall not be more than 12 times its thickness. If the length of unsupported wall is more than 12 times its thickness, buttressing shall be provided. 
C NC N/A HEIGHT OF WALLS: The thickness to height ratio of a wall shall not be more than 1:8 for stone building and 1:12 for brick building.

C NC N/A OPENINGS IN WALL: The maximum combined width of the openings on a wall between two consecutive cross-walls shall not be more than $35 \%$ of the total wall length for one-storey building and not more than $25 \%$ of the total wall length in two storey building.

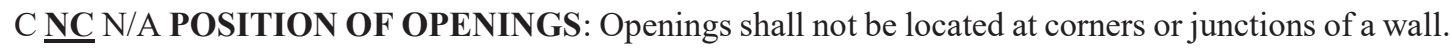
Openings shall not be placed closer to an internal corner of a wall than half the opening height or 1.5 times the wall thickness, whichever is greater. The width of pier between two openings shall not be less than half of the opening height or 1.5 times the wall thickness, whichever is greater. The vertical distance between two openings shall not be less than $0.6 \mathrm{~m}$ or half the width of the smaller opening, whichever is greater.

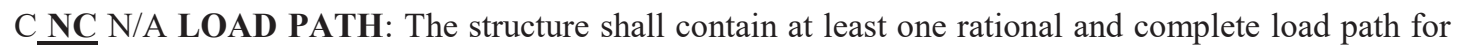
seismic forces from any horizontal direction so that they can transfer all inertial forces in the building to the foundation.

C NC N/A VERTICAL DISCONTINUITIES: All vertical elements in the lateral-force-resisting system shall be continuous to the foundation.

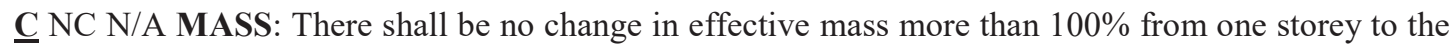
next.

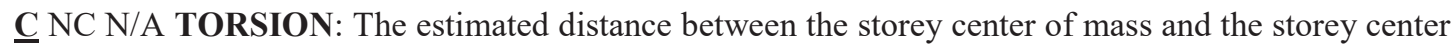
of stiffness shall be less than $30 \%$ of the building dimension at right angles to the direction of loading considered.

C $\underline{\text { NC }}$ N/A MASONRY UNITS: There shall be no visible deterioration of masonry units.

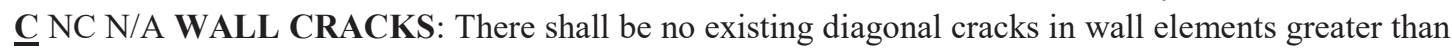
$1 / 16^{\prime \prime}$ or out-of-plane offsets in the bed joint greater than $1 / 16 "$.

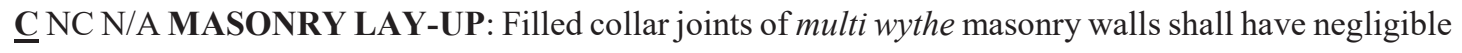
voids.

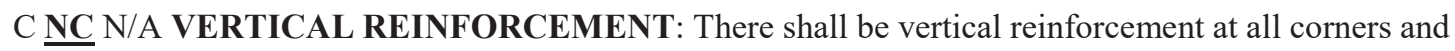
T-junctions of masonry walls and it shall be started from foundation and continuous to roof.

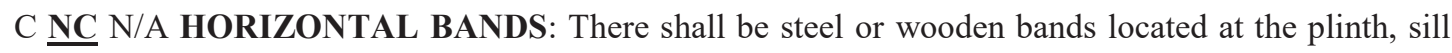
and lintel levels of the building in each floor.

C $\underline{\text { NC N}}$ /A CORNER STITCH: There shall be reinforced concrete or wooden elements connecting two orthogonal walls at a vertical distance of at least $0.5 \mathrm{~m}$ to $0.7 \mathrm{~m}$.

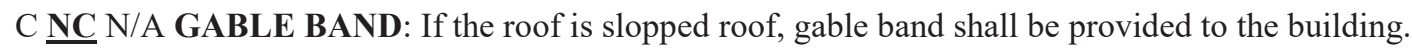

\section{Lateral Force Resisting System}

C NC N/A REDUNDANCY: The number of lines of walls in each principal direction shall be greater than or equal to 2 .

\section{Diaphragms}

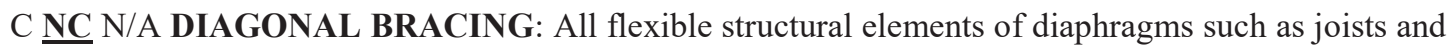
rafters shall be diagonally braced and each crossing of a joist/rafter and a brace shall be properly fixed.

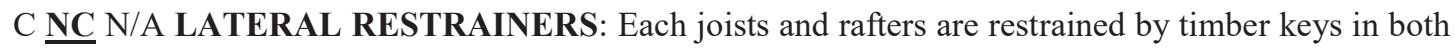
sides of wall. 


\section{Geologic Site}

C NC N/A NK AREA HISTORY: Zero Evidence of history of landslides, mud slides, soil settlement, sinkholes, construction on fill, or buried on or at sites.

C NC N/A NK LIQUEFACTION: No Liquefaction susceptible.

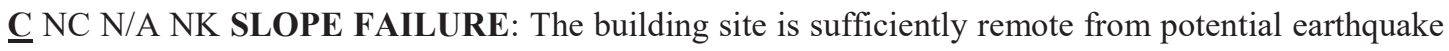
induced slope failures or rock falls to be unaffected by such failures

\section{Reinterpretation of the Building Fragility Based on Observed Vulnerability Factors}

After thorough analysis and interpretation of vulnerability factors, the building is categorized as average of that particular building typology, according to which the probable performance of the building at different intensities of earthquake in terms of damage grade is expected to be moderate to heavy. Figure Explaining Damage Grade[1]

\begin{tabular}{|l|l|}
\hline & $\begin{array}{l}\text { Structural damage : No } \\
\text { Non-structural damage: Slight } \\
\text { - Hair-line cracks in very few walls. } \\
\text { - Fall of small pieces of plaster only. } \\
\text { - Fall of loose stones from upper parts of } \\
\text { buildings in very few cases. }\end{array}$ \\
\hline
\end{tabular}




\subsection{CONCLUSIONS AND RECOMMENDATION}

The safety of the building is inadequate and the building is in imminent danger of collapse in the event of an earthquake. The building is suggested to retrofit. But the proposed retrofit scheme should be technically feasible and economically viable (Usually retrofitting is considered suitable if the cost of retrofitting is within $30 \%$ of the cost of new construction).

\section{QUANTITATIVE SEISMIC VULNERABILITY ASSESSMENT}

\subsection{INTRODUCTION}

This second phase study of seismic vulnerability assessment which is a quantitative approach and follows qualitative analysis. Before embarking on seismic retrofitting, seismic deficiencies shall have to be identified through a seismic evaluation process using a methodology described previous. The first phase assessment is general seismic vulnerability assessment method based on qualitative approach to identify the seismic deficiencies in the building. If the first phase study finds seismic deficiencies in the building and possible seismic performance is not up to the acceptable level/criteria, it recommends either second phase assessment or concludes the evaluation and state that potential deficiencies are identified. The second phase assessment involves a more detailed seismic evaluation with complete analysis of the building for seismic strengthening measures as modifications to correct/reduce seismic deficiencies identified during the evaluation procedure in first phase. Detail information about the building is required for this step of evaluation. Seismic retrofit becomes necessary if the building does not meet minimum requirements of the current Building Code, and may suffer severe damage or even collapse during a seismic event.

The most important issue when beginning to evaluate the seismic capabilities of an existing building is the availability and reliability of structural drawings. Detailed evaluation is impossible without framing and foundation plans, layout of preliminary lateral force elements, reinforcing for concrete structures, and connection detailing. This chapter assumes that sufficient information is available to perform a seismic evaluation that will identify all significant deficiencies.

\subsection{REVIEW INITIAL CONSIDERATIONS}

Review of Qualitative Analysis is done.

\subsection{DECIDE PERFORMANCE OBJECTIVE}

The performance objective needs to be defined before analyzing the building for retrofit. The performance objective depends on various factors such as the use of building, cost and feasibility of any strengthening project, benefit to be obtained in terms of improved safety, reduction in property damage, interruption of use in the event of future earthquakes and the limiting damage states. The minimum objective considered here is Life Safety i.e. any part of the building should not collapse threatening safety of occupants during a severe earthquake.

\subsection{DESIGN BASIS EARTHQUAKE}

Seismic hazard due to ground shaking shall be based on the location of the building with respect to causative faults, the regional and site-specific geologic characteristics, and a selected earthquake hazard 
level. Seismic hazard due to ground shaking shall be defined as acceleration response spectra or acceleration time histories on either a probabilistic or deterministic basis. Seismic strengthening of buildings shall comply with the design criteria and procedures as specified in national building codes and standards of earthquake engineering.

A building must have been designed and constructed or evaluated in accordance with the current seismicity of the region

\subsection{DETAILED INVESTIGATION}

For evaluation of member capacities, precise values of the material strength and the dimensions are desirable. For this, various techniques are employed for determining the strength of the material.

Tests

\section{Masonry Wall}

China-Nepal joint experiment of retrofit project was held successfully at Kunming, Yunnan Province on 21-22 January 2017.International Center for Collaborative Research on Disaster Risk Reduction

Unit Weight of Masonry $=22 \mathrm{KN} / \mathrm{m}^{3}$

Modulus of Elasticity $(\mathrm{E})=74 \mathrm{MPa}$ (From China Wall test)

Allowable Compressive Strength $=0.49 \mathrm{MPa}$

Allowable Tensile Strength= Neglected

Allowable Shear Strength= $0.096 \mathrm{MPa}$ (From Shake table test) (40\% of Ultimate)

\section{Teak Wood}

Wt. per unit Volume $=0.000007 \mathrm{~N} / \mathrm{mm}^{3}$

Modulus of Elasticity $(\mathrm{E})=9400 \mathrm{MPa}$

Shear Modulus $(\mathrm{G})=4086.96 \mathrm{MPa}$

\subsection{SEISMIC ANALYSIS AND DESIGN}

The detail seismic evaluation refers to the structural analysis of the building. Structural analysis is a part of the detailed evaluation of an existing building. The method of analysis is to be finalized at this stage based on building data. The evaluation procedure includes an analysis using Linear Dynamic procedure. The steps include developing a computational model of the building, applying the external forces, calculating the internal forces in the members of the building, calculating the deformations of the members and building, and finally interpreting the results. The structural analysis is performed using a suitable computer analysis program. The relevant seismic code is referred for lateral load calculation. The model is analyzed for the individual load cases after the computational model is developed and the loads are assigned. 


\section{ETABS OUTPUT CONVENTION FOR SHELL ELEMENT INTERNAL FORCES}

The shell element internal forces, like stresses, act throughout the element. They are present at every point on the mid-surface of the shell element. ETABS reports values for the shell internal forces at the element nodes. It is important to note that the internal forces are reported as forces and moments per unit of in-plane length. Output Convention for Shell Stresses [8]

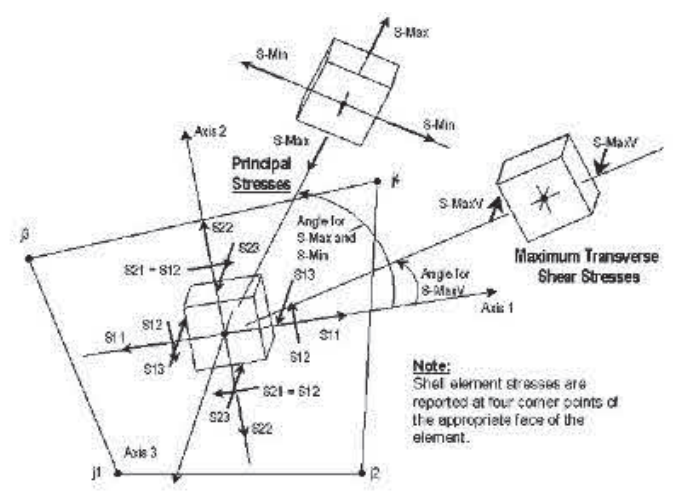

The figure above illustrates the positive directions for shell element internal stresses S11, S22, S12, S13 and S23. Also shown are the positive directions for the principal stresses, S-Max and S-Min, and the positive directions for the maximum transverse shear stresses, S-Max-V.

\section{LOAD CONSIDERED FOR THE ANALYSIS:}

- $\mathrm{DL}$

- LL

- $\mathrm{EQ}$

\section{GRAVITY AND LATERAL LOAD ANALYSIS}

Linear and elastic finite element Model was run for the Lateral load corresponding to the basic seismic coefficient of 0.45 (Critical of both NBC 105:1994 and IS 1893:2016). [7] [9]

\section{LOAD COMBINATION: FOR WORKING STRESS METHOD AS PER NBC 105:1994}

- $\mathrm{DL}+\mathrm{LL}$

- $\quad 0.7 \mathrm{DL}+\mathrm{EQx}$

- $\quad 0.7 \mathrm{DL}-\mathrm{EQx}$

- $\quad 0.7 \mathrm{DL}+\mathrm{EQy}$

- $\quad$ 0.7DL-EQy

- $\mathrm{DL}+\mathrm{LL}+\mathrm{EQx}$

- DL+LL-EQx

- $\mathrm{DL}+\mathrm{LL}+\mathrm{EQy}$

- DL+LL-EQy 


\section{LATERAL LOAD CALCULATION}

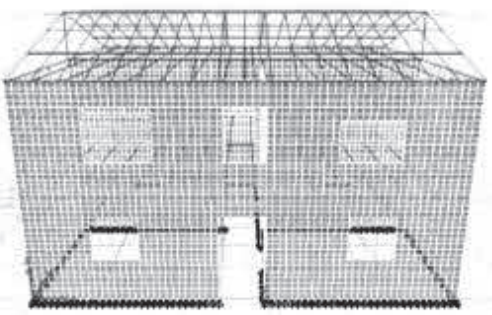

Figure: Finite Element Modelling of Study Building

- $\quad$ Age of Building: 3 Years

- Shape: Rectangular

- Storey: Two

○ Length:9042 mm (29ft 8in)

- $\quad$ Breadth:8077mm (26ft 6in)

○ Height:5766 mm (18ft 11in)

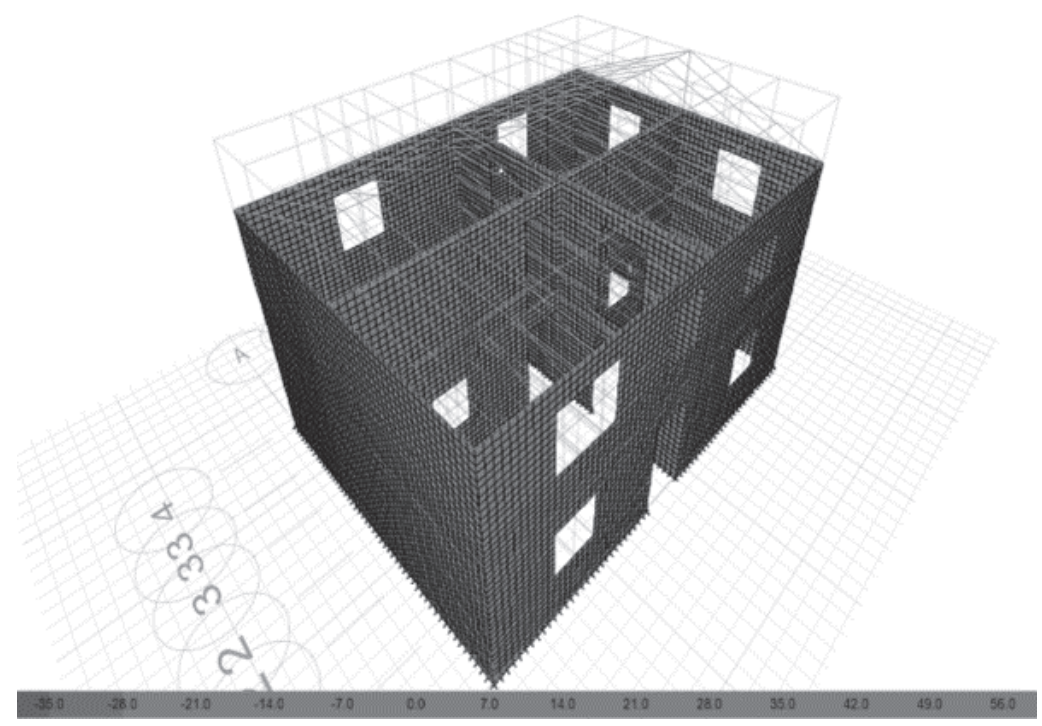

Figure: Calculation of Stress 


\section{CHECK FOR COMPRESSIVE STRESS}

Compressive Stress S22 demand in load bearing Stone Masonry Wall due to Site Specific Earthquake loading is well within permissible limits except in very Small location of Stress Concentrations at Corners. Also, according to data sheet from Etabs Tension are predominant on some of the critical section of the Building so to resist both stress Building should follow Retrofitting methods.

\section{RETROFITTING METHODS}

\subsection{SPLINT AND BANDAGE}

- $\quad$ Suitable up to three storey, preferable for two storey

- Intervention time-Moderate

- Cost-Moderate

- $\quad$ Performance Level-Life Safety

The Splint and Bandage system is considered as an economic version of jacketing where reinforcing bars are provided at most critical locations (Figure 6), wherever stress concentrations can develop. Splints are vertical elements provided at corners, wall junctions and jambs of openings in the external faces of the building. The objective is to provide integrity in vertical direction.

The bandages are horizontal elements running around all the walls and building to integrate various walls together thereby preventing potential out of plane collapse of walls. In addition, openings are also surrounded by splints and bandages to prevent initiation and widening of cracks from their corners. Splints are provided in the external face only. The bandages could be provided on both the faces of the walls just at the lintel, eaves and sill level. This method is inferior to jacketing but better than bolting as discussed below in terms of safety enhancement.

The Gorkha Earthquake-2015, has damaged many buildings of Kathmandu valley. The seismic enhancing elements are missing in most of the masonry buildings of Nepal. So, such buildings were effected more by the Gorkha earthquake. Such buildings are highly vulnerable to future larger earthquakes. The studied building is also found to be highly vulnerable in future large earthquakes. But the seismic performance capacity of the buildings can be enhanced by various techniques of retrofitting. The same suggestion is given for the building of Administrative Staff College. As the building is comparatively a heavy structure with poor seismic enhancing elements, the cost of retrofitting will be higher in comparison to the ordinary residential masonry building. However, the building can be made safer and serviceable by appropriate techniques of retrofitting. 


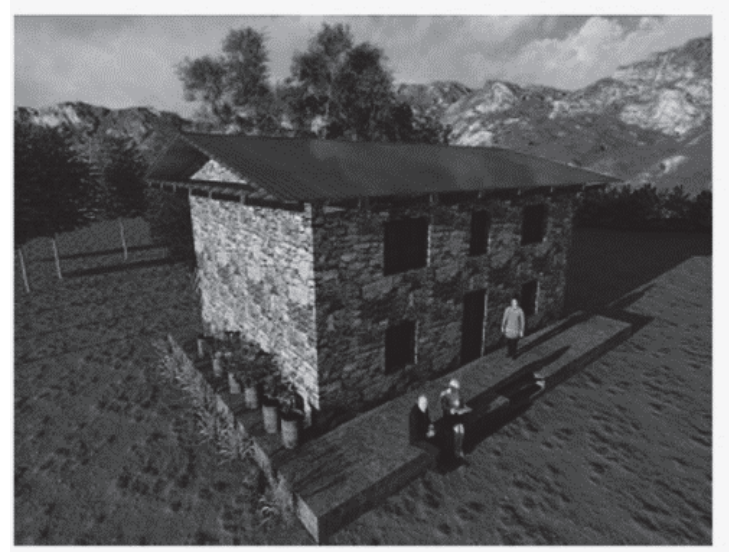

Figure: Sketch up modelling of Considered Building

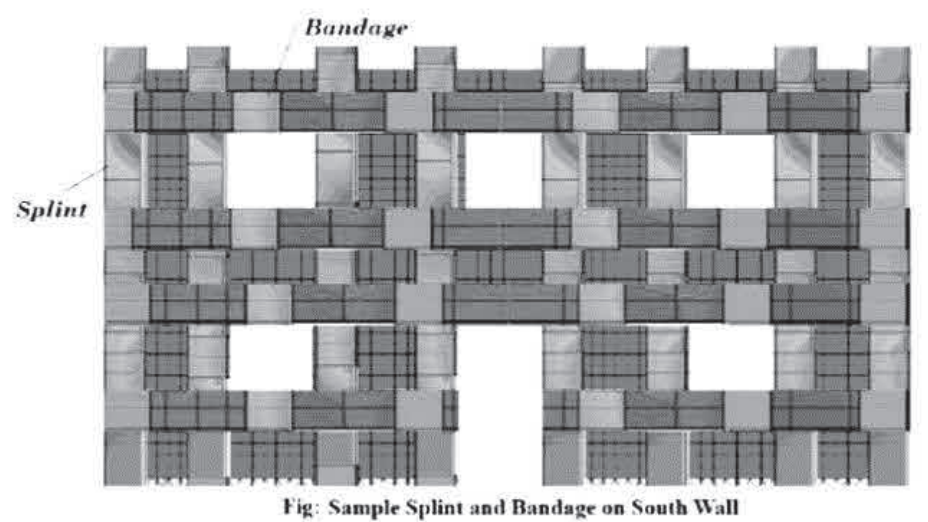

Figure: Sample Splint and Bandage Retrofitting on South Wall of Considered Building

\section{CONCLUSION}

Many past Earthquake including Major Gorkha Earthquake and its aftershocks have damaged prevailing stone masonry dwellings within our country so seismic enhancing of such damaged building is very essential to make reconstruction and as a whole living better. So seismic vulnerability of such building should be done more precisely and retrofitting options should be suggested to such buildings as done in this research.

\section{ACKNOWLEDGMENT}

I would like to acknowledge with more appreciation to all the faculty members, seniors and my classmates of the Master's in Earthquake Engineering Institute of Engineering, Thapathali Campus for their encouragements, inspirations and suggestions. I am as well grateful to all the people who have contributed to my research work. 


\section{REFERENCES}

[1] Government of Nepal- Ministry of Physical Planning and Works, Seismic Vulnerability Evaluation Guideline for Private and Public Buildings. 2011.

[2] I. INTERNATIONAL CODE COUNCIL and ALL, INTERNATIONAL BUILDING CODE. 2009.

[3] S. Adanur, "Performance of masonry buildings during the 20 and 27 December 2007 Bala (Ankara) earthquakes in Turkey," no. December 2007, pp. 2547-2556, 2010, doi: 10.5194/nhess-10-25472010.

[4] M. of H. A. Government of Nepal, Nepal Disaster Report 2017 Ministry of Home Affairs, no. December. 2017.

[5] G. of Nepal and N. P. C. S. Central, "National Population and Housing Census 2011 (National Report) Government," vol. 01, 2012.

[6] M. Sykora, D. Diamantidis, M. Holicky, and K. Jung, "Target reliability for existing structures considering economic and societal aspects," Struct. Infrastruct. Eng., 2017, doi: 10.1080/15732479.2016.1198394.

[7] D. of U. D. and B. C. Government of Nepal, Ministery of Physical Planning and Works, "NEPAL NATIONAL BUILDING CODE NBC 105:1994 Seismic Design of Buildings in Nepal,” Nepal Natl. Build. Code, no. 10 May, 1994.

[8] CSI, “CSI Analysis Reference Manual,” I Berkeley (CA, USA) Comput. Struct. INC, 2013.

[9] IS 1893, "“Criteria for Earthquake resistant design of structures,Part 1:General Provisions and buildings,"” Bur. Indian Stand. New Delhi, vol. 1893, no. December, pp. 1-44, 2016. 